\title{
The Actions of Secretagogues on Oxygen Uptake by Isolated Mammalian Parietal Cells
}

\author{
ANDREw H. SolL, Veterans Administration Wadsworth Hospital Center, \\ Los Angeles, California 90073, and the University of California at \\ Los Angeles School of Medicine, Los Angeles, California 90024
}

\begin{abstract}
A B S T R A C T The action of histamine, carbamylcholine, and gastrin on oxygen uptake by cells isolated from canine fundic mucosa was studied in vitro. Viable mucosal cells were prepared by exposure of separated mucosa sequentially to collagenase and EDTA. Oxygen consumption, determined by polarography, was chosen as an index of physiological response of mucosal cells to secretagogues.

Isobutyl methyl xanthine (IMX), carbamylcholine, histamine, and gastrin each independently stimulated oxygen uptake by the unfractionated mucosal cells. The response to histamine was greatly enhanced when IMX was present. In fractions of varying parietal cell content obtained with the Beckman elutriator rotor, basal and stimulated oxygen uptake correlated with the parietal cell content of the fractions. The percentage increases in oxygen uptake in response to histamine, gastrin, carbamylcholine, and IMX were similar in enriched fractions with from 50 to $85 \%$ parietal cells and in unenriched starting fractions. The normalized doseresponse relations for histamine with an IMX background and for carbamylcholine were also similar in these two fractions.

The specificity of these responses was tested by use of an $\mathrm{H}_{2}$-histamine receptor antagonist, metiamide, and an anticholinergic agent, atropine. At the doses used, neither metiamide $(0.1 \mathrm{mM})$ nor atropine $(10 \mu \mathrm{M})$ inhibited basal oxygen uptake. Histamine, studied with an IMX background, was inhibited by metiamide but not by atropine, while carbamylcholine was inhibited by atropine but not by metiamide. Neither metiamide nor atropine inhibited gastrin-stimulated oxygen uptake.
\end{abstract}

This work was presented, in part, at the meetings of the American Physiological Society, San Francisco, Calif., 7 to 10 October 1975 (1) and at the meetings of the American Gastroenterological Association, 22 to 27 May 1976, Miami, Fla. (2).

Dr. Soll is the recipient of a Research Associateship from the Veterans Administration.

Received for publication 22 September 1976 and in revised form 22 September 1977.
These data indicate that in this in vitro system parietal cells account for most of the increase in oxygen uptake produced by exposure to gastric secretagogues and that histamine, gastrin, and carbamylcholine each independently stimulate oxygen uptake by the parietal cell. The specificity displayed by atropine and metiamide in this in vitro system suggests that the parietal cell has specific receptors for each of these secretagogues.

\section{INTRODUCTION}

Histamine, gastrin, and acetylcholine, when given exogenously or when released endogenously, stimulate gastric acid secretion. It is unclear whether each of these agents directly stimulates the parietal cell (3) or whether gastrin and(or) acetylcholine work through a final common mediator such as histamine (4). Strong interactions occur between these secretagogues, as evidenced by the ability of each of these agents to enhance the actions of the other two and by the striking lack of specificity of anticholinergic drugs and $\mathrm{H}_{2}$-histamine antagonists on in vivo acid secretion (5).

Two of these agents, histamine and acetylcholine, are stored in close proximity to their target. Acetylcholine and(or) histamine may be spontaneously released from fundic mucosal stores in the basal state and may affect the responsiveness of the parietal cell to other forms of stimulation. Isolated cell systems offer the possibility of removal of tonic influences because of local release of acetylcholine and histamine, thereby allowing the effects of stimulants or inhibitors to be studied alone or in combination. Several methods for isolating parietal cells have been developed that use either pronase or crude collagenase (6-13). Although cells prepared by these methods have shown responsiveness to histamine $(7,10-12)$ and dibutyryl cyclic AMP (12), the responses have been small and inconstant, probably as a result of cell damage that occurred during preparation. The high proteolytic activity of the enzyme preparations used may account for some of 
the impairment of cell responsiveness. Croft and Ingelfinger (7) observed that removal of all submucosal elements from mucosa improved the effectiveness of subsequent enzyme digestion. Amsterdam and Jamieson, in their isolation of pancreatic cells (14), found that interrupting the enzyme incubation with a brief calcium chelation step promoted disruption of cell junctions, thereby facilitating tissue disruption without necessitating prolonged and toxic exposures to EDTA. In light of these two observations, the present method incorporates use of a mucosa completely separated from submucosa and an incubation with crude collagenase that is interrupted by a brief calcium chelation step.

In the present study oxygen consumption was chosen as an index for monitoring the physiological response of isolated parietal cells. The rationale for studying oxygen consumption is that the secretion of acid is a highly energy-dependent process (15), with a quantitative correlation apparent between oxygen consumption and acid secretion in systems such as the ex vivo stomach $(16,17)$ and the isolated amphibian mucosa (15) where both functions can be measured. In the present study, with enriched parietal cell fractions prepared by use of a Beckman elutriator rotor, a strong positive correlation between parietal cell content and both basal and stimulated oxygen uptake was demonstrated, thus indicating that oxygen consumption is a reliable index for the actions of secretagogues on isolated parietal cells.

\section{METHODS}

Earle's balanced salt solution, Hanks' balanced salt solution, and basal medium Eagle were purchased from Microbiological Associates, Bethesda, Md. Crude collagenase III was obtained from Worthington Biochemical Corp., Freehold, N. J. 3-Isobutyl-1-methyl-xanthine (IMX) ${ }^{1}$ was purchased from Aldrich Chemical Co., Inc., Milwaukee, Wis., and carbamylcholine chloride was from $\mathrm{K}$ and $\mathrm{K}$ Laboratories, Inc., Irvine, Calif. Histamine diphosphate, Hepes buffer, and atropine were purchased from Calbiochem, San Diego, Calif. Bovine serum albumin (BSA, fraction V) was from Sigma Chemical Co., St. Louis, Mo.; nytex nylon mesh was from Naz-Dar Co., Chicago, Ill. Pyroxylin strips were purchased from Mallinckrodt Inc., St. Louis, Mo., and Bourns potentiometers from Hamilton-Avnet Electronics, Hollywood, Fla. Natural hog heptadecapeptide gastrin was the kind gift of R. A. Gregory and H. J. Tracy. Metiamide was the kind gift of Dr. John Paul, Smith Kline \& French, Philadelphia, Pa. Dimethyl sulfoxide was purchased from Merck Sharp \& Dohme, West Point, Pa. A cell counter, an Electrozone/Celloscope (model 112 L/ADC) with PDP 8M computer (Digital Equipment Corp., Marlboro, Mass.), was purchased from Particle Data Inc., Elmhurst, Ill. Standard size latex particles (SR-10, 9.8- $\mu \mathrm{m}$ diameter and SR-19, 19.0- $\mu$ m diameter) were purchased from Particle Information Services, Grants Pass, Ore.

${ }^{1}$ Abbreviations used in this paper: A, atropine; BSA, bovine serum albumin; $C$, carbamylcholine; $D_{50}$, dose for $50 \%$ response; G-17, natural hog heptadecapeptide gastrin; $\mathbf{H}$, histamine; IMX, 3-isobutyl-1-methyl xanthine; Mt, metiamide.
Technique for tissue digestion. Dogs were conditioned by 1-2 wk of a diet of Friskies Kibble (Albers Milling Co., Portland, Ore.), last fed $24 \mathrm{~h}$ before the experiment, and then killed by intravenous pentobarbital sodium. The stomach was quickly excised, rapidly washed in normal saline $\left(4^{\circ} \mathrm{C}\right)$, and then transferred to Hanks' salt solution (0.1\% BSA, pH 7.4). The stomach was opened along the greater curvature, rinsed with Hanks' $(0.1 \%$ BSA), and the oxyntic gland portion cut into strips $1-2 \mathrm{~cm}$ wide. The mucosal strips were then pinned to a corkboard immersed under Hanks' $(0.1 \%$ BSA) in a Lucite chamber (E. I. Du Pont de Nemours \& Co., Inc. Wilmington, Del.) set on crushed ice. A superficial cut was made with a scalpel through mucosa only, and the mucosa was then bluntly dissected free from the submucosa. A separation of mucosa that left it totally free of submucosa was essential for the effectiveness of subsequent enzyme digestion (7). The mucosa was then lightly scraped with the edge of a glass slide to remove mucus, coarsely minced with scissors, and weighed. 5 $10 \mathrm{~g}$ of mucosa was placed into $25 \mathrm{ml}$ of basal medium (Eagle's), containing crude collagenase III $(0.75 \mathrm{mg} / \mathrm{ml})$ and incubated for $15 \mathrm{~min}$. This and the subsequent three incubations were done in 250-ml Nalgene flasks (Nalge Co., Rochester, N. Y.) gassed with $95 \% \mathrm{O}_{2} / 5 \% \mathrm{CO}_{2}$ and incubated at $37^{\circ} \mathrm{C}$ in a shaker bath at 120 oscillations/min. Basal medium for these incubations contained $25 \mathrm{mM}$ Hepes buffer, $0.1 \% \mathrm{BSA}$, penicillin $(100 \mathrm{U} / \mathrm{ml})$, and streptomycin $(50 \mu \mathrm{g} / \mathrm{ml})$, with the $\mathrm{pH}$ adjusted to 7.4 after gassing. At the end of this first incubation period the contents of the flasks were pooled in a $250-\mathrm{ml} \mathrm{Nal}$ gene beaker, the mucosal fragments allowed to settle, and the medium aspirated and discarded. The fragments were rinsed twice in cation-free basal medium with 1-2 mM EDTA and incubated in the same medium for $10 \mathrm{~min}$.

The suspensions were then pooled and the mucosal fragments were transferred to basal medium with crude collagenase $(0.75 \mathrm{mg} / \mathrm{ml})$ present and incubated for $15 \mathrm{~min}$. A similar transfer was then made to a final 60 -min incubation in this same medium. For the final $30 \mathrm{~min}$ of the fourth incubation period, the shake speed was increased to 130 oscillations $/ \mathrm{min}$, after which the mucosal fragments were largely disrupted in most instances. Some variability in the degree of cellular dispersion was noted; adequate dispersion could usually be obtained by increasing the EDTA concentration to $2 \mathrm{mM}$.

The cell suspensions were then pooled, diluted with an equal volume of Hanks' ( $1 \% \mathrm{BSA}, \mathrm{pH} 7.4)$ at $4^{\circ} \mathrm{C}$ drawn three times into a $20-\mathrm{ml}$ plastic syringe, and passed through a $240-$ $\mu \mathrm{m}$ Nytex nylon mesh. $20-\mathrm{ml}$ portions of the cell suspension were spun at $50 \mathrm{~g}$ for $5 \mathrm{~min}$ in $50-\mathrm{ml}$ centrifuge tubes (Corning Glass Co., Corning, N. Y.), with supernates being aspirated and discarded. The cells were resuspended in $20 \mathrm{ml}$ of Hanks' $(1 \% \mathrm{BSA})$ and centrifuged again at $50 \mathrm{~g}$ for $5 \mathrm{~min}$. After a final resuspension, the cells were passed through a $62-\mu \mathrm{m}$ nylon mesh. The cell suspension then consisted of single cells with occasional clumps. In 35 consecutive cell preparations, viability determined by exclusion of trypan blue was $94.2 \pm 0.8 \%$, and the yield of mucosal cells was $69.7 \pm 5.5 \times 10^{6}$ cells $/ g$ of separated mucosa.

Technique for histologic studies. Samples for routine staining were prepared either by smearing cell suspensions on frosted slides followed by fixation with Spray-cyte (Clay Adams, Parsippany, N. J.) or by fixing with Bouin's solution ( $1 \%$ acetic acid) followed by paraffin embedding and sectioning. For the latter technique, cells were washed in $70 \%$ alcohol and then transferred to pyroxylin bags which were then tied, trimmed, and placed in cassettes for Technicon processing (Technicon Instruments Corp., Tarrytown, N. Y.). Proxylin bags were prepared by filling 15ml conical glass centrifuge tubes with $8 \%$ pyroxylin dissolved in ether-alcohol (1:1). After $15 \mathrm{~min}$ the solidified top of the 
pyroxylin was removed, the pyroxylin poured back into the stock solution, and the tube drained upside down; the coated test tube was soaked in water and the bag removed by gentle traction. With this technique all cells were preserved for differential counting. Parietal cells were easily identified with hematoxylin and eosin staining and were found to account for from 10 to $25 \%$ of the crude cell population. Similar differential counts were also obtained by counting the large, finely granular cells in fresh smears.

Technique of cell separation. A Beckman elutriator rotor which separates cells by counterflow centrifugation on the basis of varying sedimentation velocity (18) was used on a Beckman J21C centrifuge (Beckman Instruments, Inc., Fullerton, Calif.). The centrifuge was modified by replacing the $3,000-\mathrm{ohm}$ rate controlling potentiometer with a 2,500-ohm fixed resistor (5 watt) in series with a 500 -ohm 10-turn potentiometer (Bourns, Inc,, Riverside, Calif., 3400S-1-501). This modification allowed reproducible control of the rate of rotation $( \pm 10 \mathrm{rpm})$ over the range of 800 to $4,500 \mathrm{rpm}$. A Cole-Parmer Masterflex pump (7545, with 7014 head, ColeParmer Instrument Co., Chicago, Ill.) was also modified using a 10-turn potentiometer $(20,000 \mathrm{ohm}$, Bourns $3500 \mathrm{~S}-1-501)$ which allowed control of flow rate between 8 and $75 \mathrm{ml} / \mathrm{min}$ with an accuracy of $\pm 1.2 \%$. The Beckman bypass loading chamber was removed and the pump connected directly to the inlet port of the elutriator. Cells were loaded through the pump with a three-way stop cock to avoid the necessity of stopping the pump during the loading procedure. Hanks' with $0.1 \%$ BSA was used for elutriation. Cell separations were performed at $2,000 \mathrm{rpm}$, with the rate confirmed by stroboscopic tachometer.

$1-2 \times 10^{8}$ cells were loaded into the elutriator at a flow rate of $16.0 \mathrm{ml} / \mathrm{min}$. At this flow rate erythrocytes, cell fragments, and a portion of the smallest of the mucosal cells were removed and discarded. Four fractions were then collected as noted in Table I. 10-25\% of the cells initially loaded were collected in fraction 4 , which will be referred to as the parietal cell-enriched fraction. Fractions collected at flow rates greater than $63 \mathrm{ml} / \mathrm{min}$ contained clumps of mucosal cells and a smaller proportion of parietal cells. Although occasional clumps of small cells occurred in fractions collected below $59.1 \mathrm{ml} / \mathrm{min}$, clumps containing parietal cells were not found.

A fraction containing $85 \%$ parietal cells was obtained by reloading fraction 4 into the elutriator rotor at a flow rate of $31.0 \mathrm{ml} / \mathrm{min}$ and collecting the fractions eluted at centrifuge speeds between 1,600 and $1,400 \mathrm{rpm}$. This variation in centrifuge speed appeared to enhance parietal cell enrichment, but could not be used for initial elutriations because of frequent clump formation in the rotor when crude cell preparations were introduced at low flow rates and low centrifuge speeds.

Both of these techniques occasionally failed to produce significant enrichment in the parietal cell population. Poor resolution was often associated with increased clump formation in the rotor but remained unexplained in other instances.

Technique for determination of oxygen consumption. The final cell suspension was centrifuged at $50 \mathrm{~g}$ for $5 \mathrm{~min}$ and then resuspended in Earle's balanced salt solution with $0.2 \%$ BSA and $25 \mathrm{mM}$ Hepes. The Earle's was saturated with 5\% $\mathrm{CO}_{2}$ in air before adding the $\mathrm{BSA}$ and the $\mathrm{pH}$ was then adjusted to 7.4. The cells were dispersed with a 10-ml pipette, the volume was adjusted to give about $10^{6}$ cells per milliliter, and the suspension was divided into $50-\mathrm{ml}$ portions in Corning tubes, which were then stored at $4^{\circ} \mathrm{C}$ until used.

Oxygen uptake was measured using a model 53 Yellow Springs Instruments Co. Oxygen Analyzer (Yellow Springs, Ohio). A preincubation step was found necessary to minimize the formation of bubbles in the incubation chambers. For this preincubation, $3.5 \mathrm{ml}$ of the cell suspension in Earle's- $\mathrm{O}_{2}$ was placed in a $60-\mathrm{ml}$ Nalgene bottle that had been pregassed with $5 \% \mathrm{CO}_{2}$ in air, $0.5 \mathrm{ml}$ of buffer or stimulants in buffer ${ }^{2}$ was added, and the suspension then was gently agitated for 5 min in a $37^{\circ} \mathrm{C}$ water bath. After preincubation, a 3-ml portion of the cell suspension was transferred to a siliconized incubation chamber of the Yellow Springs bath assembly. The bath assembly was tilted during probe placement to facilitate removal of any remaining bubbles. The rate of oxygen consumption stabilized after 2-3 min, and the decrease in the percentage of saturation of the medium was then determined over the subsequent 10 -min period. Probes were calibrated periodically during each experiment against Earle's saturated with air $/ 5 \% \mathrm{CO}_{2}$.

Several steps were necessary to guarantee reproducible results. $5 \% \mathrm{CO}_{2}$ in air was chosen rather than $5 \% \mathrm{CO}_{2} / 95 \% \mathrm{O}_{2}$ so that the air scale of the amplifiers could be used, thus allowing a larger relative decrease in oxygen saturation in shorter incubation periods, and allowing use of lower cell concentrations. Reproducible data also required that the same probe, chamber location, and spinner be used throughout the experiment. The tension of the Teflon membrane covering the cathode tip of the probe affected the apparent rate of oxygen consumption so that care was taken to set the same tension for the two probe membranes and not to disturb the membrane during the experiment. Basal uptake was repeatedly determined and if a significant deviation occurred, the probes were rebuilt and the basal and stimulated oxygen uptakes verified.

Calculation of data and statistical treatment. The rate of oxygen consumption was reflected in the difference between the percent oxygen saturation at the beginning and end of the 10-min incubation period. The data were analyzed in three ways. (a) In most experiments the basal rate of oxygen consumption remained constant, thereby allowing test runs to be expressed as the percent stimulation above the mean basal rate. (b) Data have been expressed as the percentage of the maximal increase above basal, calculated as follows:

$$
\% \text { maximal response }=\frac{\mathrm{O}_{2 \text { test }}-\mathrm{O}_{2 \text { basal }}}{\mathrm{O}_{2 \text { max }}-\mathrm{O}_{2 \text { basal }}} \times 100,
$$

where $\mathrm{O}_{2}$ represents the decrease in percentage of $\mathrm{O}_{2}$ saturation observed during a $10-\mathrm{min}$ period. This normalization allows comparison of data from separate experiments despite differences in parietal cell content and responsiveness, and thus is very useful for studying dose-response relationships, the effects of inhibitors, and interactions between secretagogues. Furthermore, a decay in the maximal response to stimulation of up to $5 \%$ per hour was often found. For this reason, experiments were done on the same day that the cells were prepared and the maximal response was tested at the beginning and periodically during each experiment. With the data expressed as the percentage of the mean maximal response and with the data sets limited in size so that decay was less than $10-15 \%$ of the initial maximal response, this decay was largely compensated. (c) Assuming an oxygen solubility coefficient of $22.73 \mu \mathrm{l} / \mathrm{ml}$ of solution (19), the oxygen content of a physiological salt solution at $37^{\circ} \mathrm{C}$ equilibrated with $95 \%$ air/ $5 \% \mathrm{CO}_{2}$ is $4.53 \mu \mathrm{l} / \mathrm{ml}$. Using this constant, the oxygen consumption per hour was calculated and corrected for cell con-

${ }^{2}$ Other vehicles used for solubilizing agents were as follows: 1-2 mg of G-17-I was dissolved in $50 \mu \mathrm{l}$ of dimethyl sulfoxide, diluted in distilled water and stored as an $800-\mu \mathrm{M}$ solution, diluted as required with Earle's; histamine $(80 \mathrm{mM})$ was dissolved in $0.001 \mathrm{~N} \mathrm{HCl}$; and metiamide $(40 \mathrm{mM})$ was dissolved in $0.08 \mathrm{~N} \mathrm{HCl}$. These vehicles in concentrations used did not alter basal or stimulated oxygen uptake. Other agents were dissolved in water or Earle's; all dilutions were made in Earle's. 
centration. Basal rates of oxygen consumption are presented in Fig. 2 and allow the absolute increment in oxygen uptake produced by a given agent to be calculated from the percent stimulation.

The means of the basal and stimulated oxygen uptake for the individual cell preparations were calculated from 2 to 12 tests each. These cell preparations means were then used to calculate the standard errors shown in the figures and used to determine the significance of differences by Student's $t$ test (20); $n$ was therefore equal to the number of cell preparations. The only exceptions are Fig. 4A, where standard errors for individual tests on a single cell preparation are shown, and Table III, where standard errors are based upon tests pooled from two preparations.

\section{RESULTS}

\section{Relationship between parietal cell content and basal and stimulated oxygen uptake}

Histamine, gastrin, carbamylcholine, and IMX each stimulated oxygen uptake by unenriched mucosal cells; the response to histamine was greatly enhanced by the presence of $0.1 \mathrm{mM}$ IMX (Fig. 1). To establish the component of these responses due to the parietal cells, basal and stimulated oxygen uptake were determined in five experiments on fractions with varying parietal cell content obtained using the Beckman elutriator rotor as outlined in Methods. Size distribution profiles for the unenriched fraction and representative examples of fractions 1,2 , and 4 (Table I) are shown in Fig. 2. The crude fraction shows a broad distribution of cell sizes. Fraction 1 consists of mainly small cells with a mean cell diameter of $10 \mu \mathrm{m}$. Fraction 2 consists of medium size cells with a mean diameter of about $12 \mu \mathrm{m}$. Fraction 4 is the parietal cell enriched fraction, containing $65 \%$ parietal cells in this preparation. The mean parietal cell diameter was estimated at $18.5 \mu \mathrm{m}$.

Oxygen uptake was studied in separated cell fractions from five cell preparations. Basal oxygen uptake

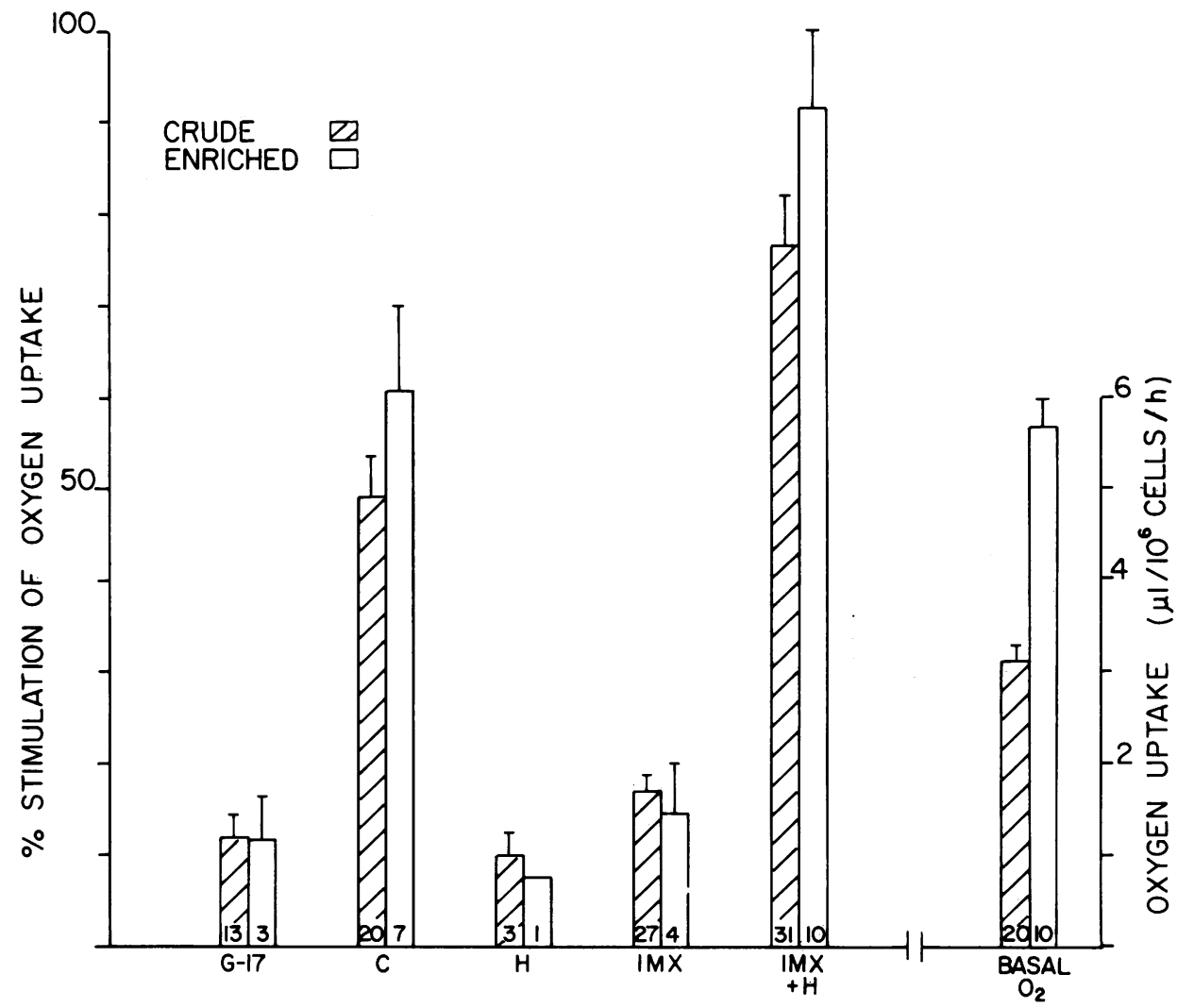

FIGURE 1 Stimulation by secretagogues of oxygen uptake in crude and enriched cell fractions. Oxygen uptake was determined on crude mucosal cell fractions (cross-hatched bars) and fractions enriched in parietal cells (fraction 4, open bars) by use of the Beckman elutriator rotor as outlined in Methods. Oxygen uptake is expressed as the mean percentage stimulation above basal $\pm \mathrm{SEM}$, based upon the means for the indicated number of cell preparations with from 2 to 12 tests each. Agents were tested at the following concentrations: $0.1 \mu \mathrm{M}$ gastrin, $1 \mathrm{mM}$ carbamylcholine, $10 \mu \mathrm{M}$ histamine, $0.1 \mathrm{mM} \mathrm{IMX}$, and $10 \mu \mathrm{M}$ histamine plus $0.1 \mathrm{mM}$ IMX. Basal oxygen uptake in microliters per $10^{6}$ cells per hour is indicated on the right of the figure for the crude and parietal cellenriched fractions. C, carbamylcholine; G-17, natural hog heptadecapeptide gastrin; H, histamine. 
TABLE I

Cell Separation with the Elutriator Rotor

\begin{tabular}{ccc}
\hline Fraction & Flow rate* $^{*}$ & Parietal cells \\
\hline & ml/min & $\%$ \\
1 & 26.3 & $1-3$ \\
2 & 36.8 & $8-12$ \\
3 & 40.7 & $20-30$ \\
4 & 59.1 & $48-65$ \\
\hline
\end{tabular}

* Maintained until a $100-\mathrm{ml}$ fraction was collected.

(microliters per $10^{6}$ cells per hour) for the parietal celldepleted fraction (fraction 1) was $1.24 \pm 0.09(n=5)$, and neither histamine $(1.29 \pm 0.08, n=5)$ nor carbamylcholine $(1.43 \pm 0.12, n=3)$ significantly stimulated oxygen uptake in this fraction. In the enriched fractions ${ }^{3}$ from these five preparations, which contained from 48 to $65 \%$ parietal cells, basal oxygen uptake (microliters per $10^{6}$ cells per hour) was $6.73 \pm 0.59$ and increased to $13.55 \pm 1.36$ with histamine $(10 \mu \mathrm{M})$ plus IMX $(0.1 \mathrm{mM})$ stimulation. Fractions 2 and 3 , with fewer parietal cells showed intermediate values for basal and stimulated oxygen uptake. Linear regression analysis of the data from these five preparations showed that basal oxygen uptake correlated with the percentage of parietal cells with a correlation coefficient of 0.95 , a slope of 0.098

\footnotetext{
${ }^{3}$ Fraction 4 in Table $I$ will be referred to as the enriched
} parietal cell fraction. \pm 0.008 and a $y$ intercept of $1.25 \pm 0.26$ (Fig. 3A). The histamine plus IMX-stimulated increment in oxygen uptake above basal also correlated with the percentage of parietal cells, with a correlation coefficient of 0.93 , a slope of $0.0125 \pm 0.0012$ and a $y$ intercept of -0.34 \pm 0.40 (Fig. 3B). Based upon these regression analyses, the basal oxygen uptake per $10^{6}$ parietal cells is predicted to be $9.81 \mu \mathrm{l} / \mathrm{h}$, basal oxygen uptake per $10^{6}$ nonparietal cells is predicted to be $1.25 \mu \mathrm{l} / \mathrm{h}$, and the histamine plus IMX-stimulated increment above basal is predicted to be $12.5 \mu \mathrm{l} / \mathrm{h}$ per $10^{6}$ parietal cells.

The carbamylcholine (1 $\mathrm{mM})$-stimulated increment in oxygen uptake above basal correlated with the parietal cell content, with a correlation coefficient of 0.95 , and a slope of $0.062 \pm 0.007$ ( $n=3$ preparations). The gastrin $(0.1 \mu \mathrm{M})$-stimulated increment in oxygen uptake above basal also correlated with the percentage of parietal cells, with a correlation coefficient of 0.97 and a slope of $0.015 \pm 0.002(n=2$ preparations).

Basal and stimulated oxygen uptake by the crude mucosal cell fractions ${ }^{4}$ were close to the values predicted from their parietal cell content (Figs. 3A and B) indicating that elutriation did not markedly impair the responsiveness of the parietal cell. The elutriator rotor allowed separation from the single cells of the small number of clumps containing parietal cells. Histamine $(10 \mu \mathrm{M})$ plus IMX $(0.1 \mathrm{mM})$ stimulation of the fraction

"The term "unenriched" will be used interchangeably to refer to the crude mucosal cell preparations.

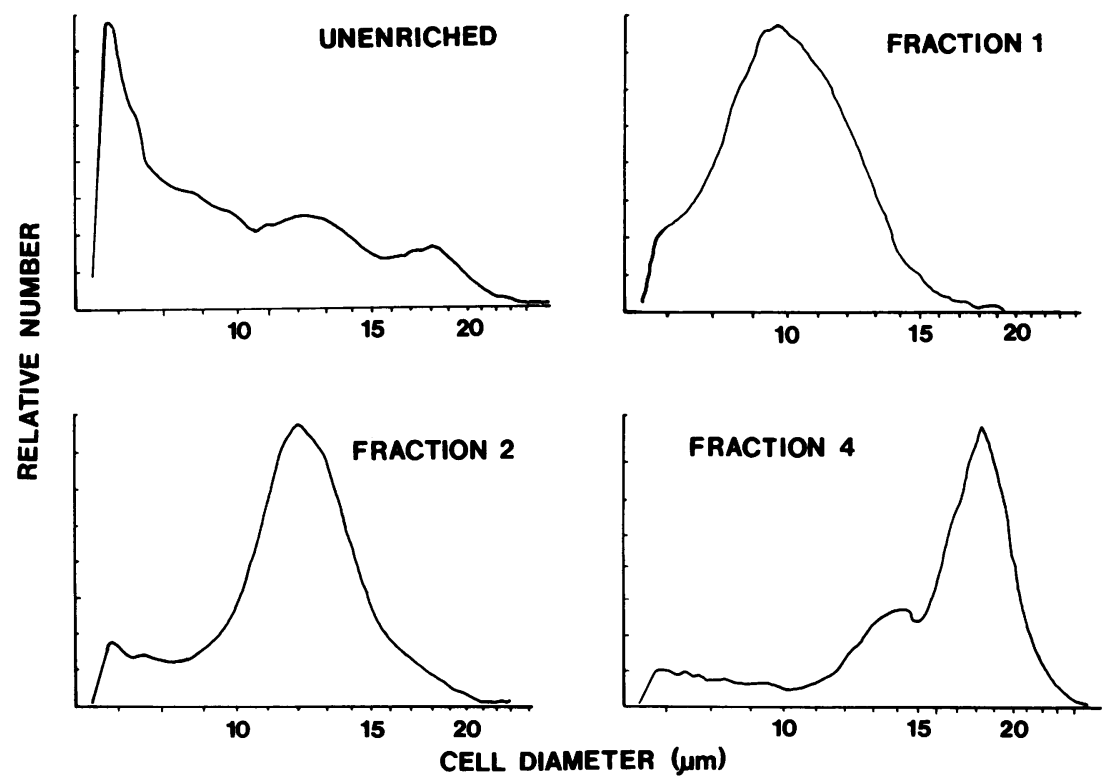

FIGURE 2 Size distribution profiles for separated cell fractions. Size histograms, plotted as the relative frequency against the cell diameter in micrometers, were obtained using a 10-vol-doubling log scale calibrated with two sets of latex particles. These four histograms are from a single preparation with the fractions collected at the flow rates indicated in Table I. 


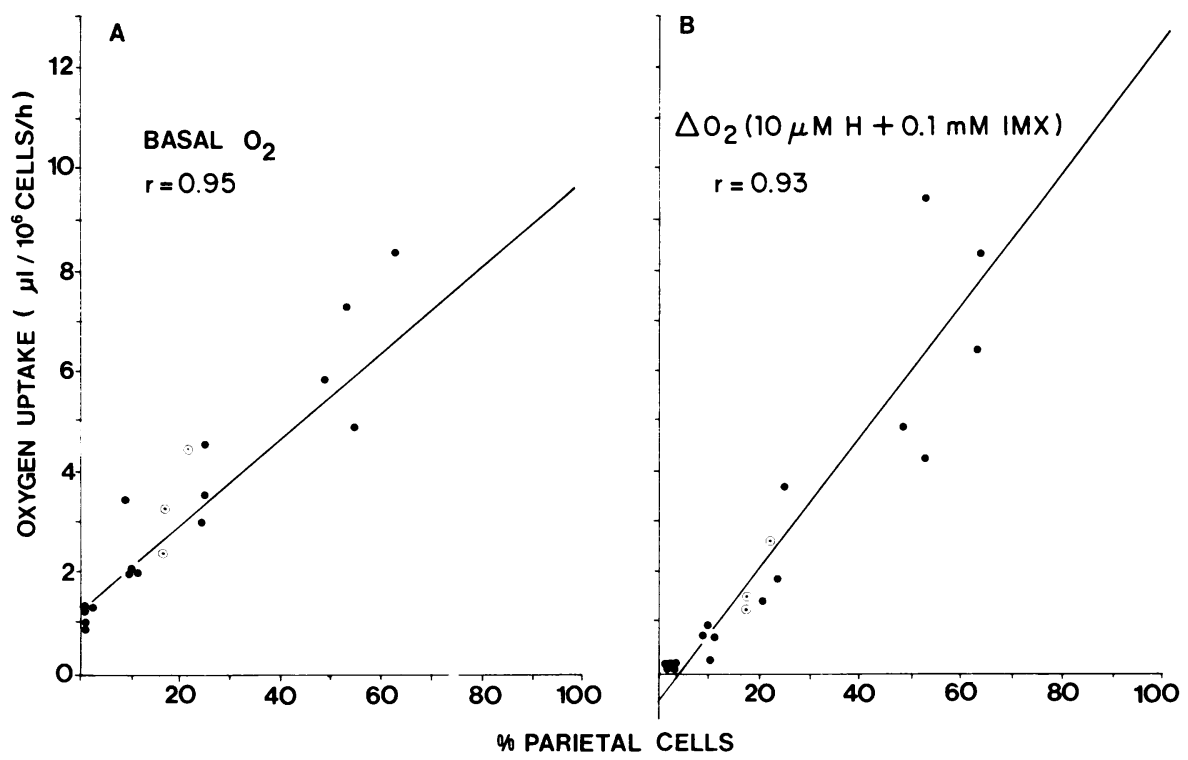

FIGURE 3 Correlation between basal and stimulated oxygen uptake and the parietal cell content. The data represent separated cell fractions of varying parietal cell content obtained with the Beckman elutriator rotor $(0)$ and the unenriched fraction $(O)$ and are the mean of at least duplicate determinations from a total of five cell preparations. The lines are drawn by linear regression analyses, with the correlation coefficients indicated. (A) The basal oxygen uptake in microliters per $10^{6}$ cells per hour is plotted against the percentage of parietal cells. (B) The histamine (10 $\mu \mathrm{M})$ plus IMX $(0.1 \mathrm{mM})$ stimulated increment in oxygen uptake above basal is plotted in the same units against the percent parietal cells.

containing the persisting clumps did not differ from that predicted by its parietal cell content, thus indicating that the presence of a small number of clumps did not alter the results obtained (data not shown).

\section{The actions of secretagogues on oxygen uptake}

Histamine. Histamine alone produced a small stimulation of oxygen uptake in both the enriched and unenriched cell fractions (Fig. 1), an effect that was statistically significant with the unenriched cell fractions tested at 100 and $10 \mu \mathrm{M}(P<0.01$, Fig. 4B). The action of histamine was greatly enhanced by $0.1 \mathrm{mM}$ IMX; the response to the combination was much greater than the response to either agent alone (Figs. 1 and 4B). The response to $10 \mu \mathrm{M}$ histamine plus $0.1 \mathrm{mM}$ IMX in 31 consecutive preparations of unenriched mucosal cells ranged from 32 to $161 \%$ above basal and averaged 76.5 $\pm 4.2 \%$ (Fig. 1). Although the mean maximal response to histamine was greater in the enriched than in the unenriched cell fractions, owing to the variability between separate cell preparations, this difference was not statistically significant (Fig. 1).

Fig. 4A shows the dose-response relation of histamine against a $0.1 \mathrm{mM}$ IMX background in three representative preparations each of the crude and enriched fractions. When the data are expressed as absolute rates of oxygen consumption per $10^{6}$ cells, considerable variability in the magnitude of the responses between separate preparations is apparent and these differences are not fully accounted for by differences in the parietal cell content of these fractions (Fig. 4A). When these data are normalized for each preparation as a percentage of the maximal increment above basal produced by histamine plus IMX stimulation, the similarity of the histamine dose-response relation in the enriched and unenriched fractions becomes apparent (Fig. 4B). The estimated dose for $50 \%$ response $\left(D_{50}\right)^{5}$ for the histaminestimulated increment in oxygen uptake above that produced by $0.1 \mathrm{mM}$ IMX was $0.4 \mu \mathrm{M}$ and the maximal response to histamine was found at $10 \mu \mathrm{M}$ for both the unenriched cells and for the enriched cells. In two preparations tested with a $10-\mu \mathrm{M}$ IMX background, the estimated $D_{50}$ was $0.7 \mu \mathrm{M}$, and the maximal response to histamine was found at $10 \mu \mathrm{M}$.

IMX. In 27 consecutive preparations of unenriched cells the mean stimulation of oxygen uptake produced by $0.1 \mathrm{mM}$ IMX was $17.0 \pm 1.8 \%$ above basal uptake and a similar response was found in the four enriched parietal cell fractions tested (Fig. 1). The dose-response relation for IMX-stimulated oxygen uptake by unen-

\footnotetext{
${ }^{5} \mathrm{D}_{50}$ was estimated by visual inspection of the dose-response curves as the concentration producing $50 \%$ of the maximal response above basal or above the indicated background.
} 

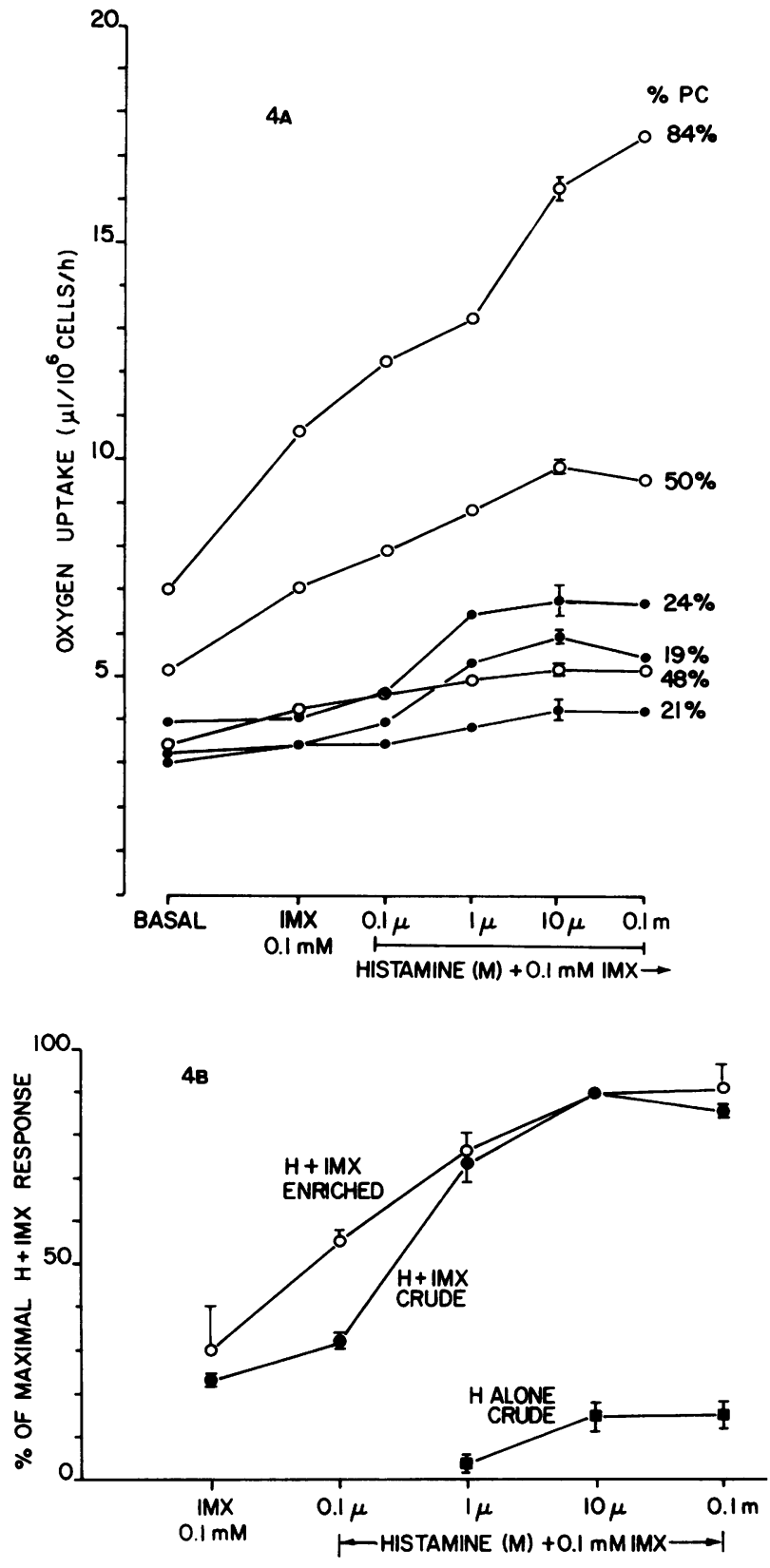

FIGURE 4 The effect of IMX on the dose-response relation to histamine. (A) Histamine stimulation of oxygen uptake was determined with a 0.1-mM IMX background and expressed microliters of $\mathrm{O}_{2}$ consumed per $10^{6}$ cells per hour. Data are the mean of at least duplicate determinations in each of three separate preparations of crude $(\Theta)$ and enriched parietal cell fractions (O). SE, based upon the individual tests in the separate cell preparations, are indicated for the $10 \mu \mathrm{M}$ histamine plus $0.1 \mathrm{mM}$ IMX. The percentage of parietal cells (\%PC) is indicated for each cell preparation. (B) The data from $A$ have been normalized as the percentage of the maximal increment above basal produced by histamine plus IMX as outlined in Methods. These data have been combined, respectively, for the three separate preparations of the crude $(O)$ and enriched $(O)$ fractions and represent the mean $\pm S E$, based upon preparation

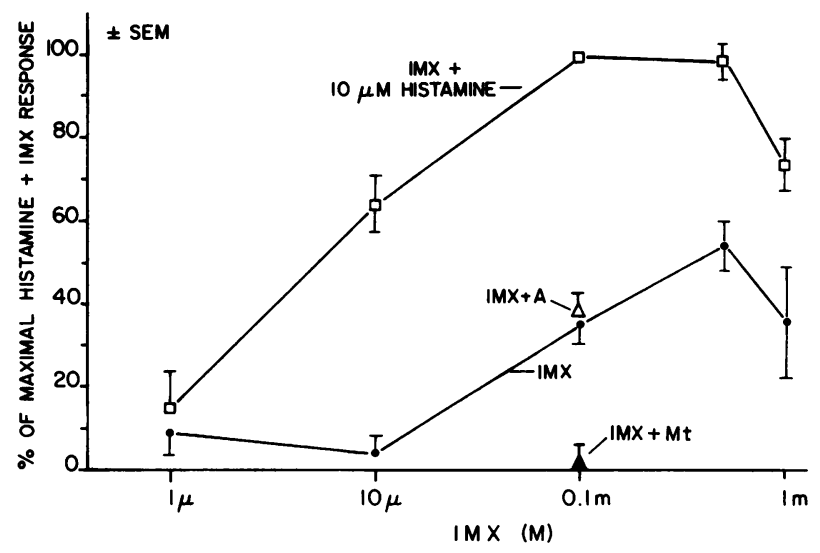

FIGURE 5 The effect of histamine on the dose-response relation to IMX. Stimulation of oxygen uptake by IMX (O), IMX plus $10 \mu \mathrm{M}$ metiamide $(\Delta)$, IMX plus $10 \mu \mathrm{M}$ atropine $(\Delta)$, and IMX plus $10 \mu \mathrm{M}$ histamine ( $\square$ ) was determined for three preparations of unenriched mucosal cells normalized as the percentage of the maximal histamine plus IMX increment above basal. The data represent the mean $\pm \mathrm{SE}$, based upon preparation means. The maximal responses to histamine plus IMX were $107.1,91.8$, and $46.0 \%$ above basal for the three preparations, respectively. A, atropine; Mt, metiamide.

riched mucosal cells had an estimated $D_{50}$ of $60 \mu \mathrm{M}$ with the maximal response observed at $0.5 \mathrm{mM}$ (Fig. 5). Higher concentrations of IMX produced a variable and somewhat diminished level of stimulation (Fig. 5). Enhancement of the response to $10 \mu \mathrm{M}$ histamine by IMX was found with IMX concentrations between $10 \mu \mathrm{M}$ and $1 \mathrm{mM}$. The maximal histamine increment over IMX was observed between $10 \mu \mathrm{M}$ and $0.1 \mathrm{mM}$ IMX and the maximal absolute response to the combination of histamine and IMX was observed between 0.1 and 0.5 mM IMX (Fig. 5).

Carbamylcholine. In 20 consecutive preparations of unenriched cells $1 \mathrm{mM}$ carbamylcholine caused 49.2 $\pm 4.2 \%$ stimulation of oxygen uptake above basal; while in seven preparations of enriched parietal cell fractions the increase was $60.9 \pm 9.2 \%$ (Fig. 1). From the doseresponse curves for carbamylcholine with enriched and crude fractions, the $D_{50}$ was estimated at $5 \mu \mathrm{M}$ and a maximal response was observed between 0.1 and $1 \mathrm{mM}$ (Fig. 6). The effect of $0.1 \mathrm{mM}$ IMX on the response to carbamylcholine was studied in five cell preparations (Table II). IMX enhanced the response to $10 \mu \mathrm{M}$ carbamylcholine but not to $1 \mathrm{mM}$ carbamylcholine. The combination of this lower concentration of carbamylcholine and IMX produced a response that was about equal to the sum of the individual responses.

Gastrin. Gastrin without additives produced a

means. The dose-response relation to histamine without IMX (ם) was studied in three preparations of crude mucosal cells and represents the mean $\pm \mathrm{SE}$, based upon preparation means. 


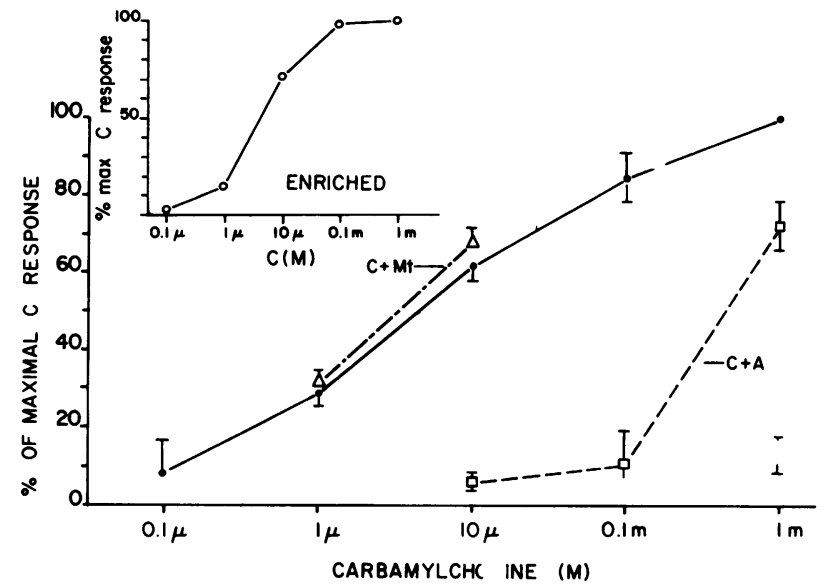

Figure 6 The effects of metiamide and atropine on the doseresponse relation to carbamylcholine. Oxygen uptake was determined for unenriched mucosal cells and expressed as the percentage of the maximal increment above basal produced by $1 \mathrm{mM}$ carbamylcholine. The data are the means $\pm S E$ from five cell preparations for carbamylcholine $(O)$ and from three preparations for carbamylcholine plus $10 \mu \mathrm{M}$ metiamide $(\Delta)$, carbamylcholine plus $0.1 \mu \mathrm{M}$ atropine $(\square)$, and carbamylcholine plus $10 \mu \mathrm{M}$ atropine $(\ominus)$. (Insert) The dose response to carbamylcholine $(O)$ was studied in an enriched cell preparation containing $51 \%$ parietal cells.

small but statistically significant stimulation of oxygen uptake. In 13 consecutive preparations of crude mucosal cells gastrin produced a $12.0 \pm 2.3 \%$ increase above basal, with a range of -2.3 to $25.1 \%$ (Fig. 1). In fractions containing from 48 to $63 \%$ parietal cells from three cell preparations, gastrin produced a $11.7 \pm 2.4 \%$ increase above basal. The effect of IMX on gastrin stimulation was studied and the magnitude of the response to gas-

TABLE II

Effect of IMX on Response to G-17 and Carbamylcholine

\begin{tabular}{|c|c|c|}
\hline & Agent & $\mathrm{O}_{2}$ uptake* \\
\hline \multirow{4}{*}{$\mathbf{A}$} & & $\%$ \\
\hline & IMX, $0.1 \mathrm{mM}$ & $21.5 \pm 2.8$ \\
\hline & C, $1 \mathrm{mM}$ & $57.8 \pm 11.3$ \\
\hline & $\mathrm{C}, 1 \mathrm{mM}+\mathrm{IMX}, 0.1 \mathrm{mM}$ & $65.4 \pm 9.5$ \\
\hline \multirow{5}{*}{ B } & $\mathrm{C}, 10 \mu \mathrm{M}$ & $30.6 \pm 5.3$ \\
\hline & $\mathrm{C}, 10 \mu \mathrm{M}+\mathrm{IMX}, 0.1 \mathrm{mM}$ & $50.6 \pm 6.3 \ddagger$ \\
\hline & IMX, $0.1 \mathrm{mM}$ & $13.9 \pm 5.1$ \\
\hline & G-17, $0.1 \mu \mathrm{M}$ & $14.3 \pm 4.5 \S$ \\
\hline & $\mathrm{IMX}, 0.1 \mathrm{mM}+\mathrm{G}-17,0.1 \mu \mathrm{M}$ & $33.3 \pm 8.5^{11}$ \\
\hline
\end{tabular}

* Percentage increase in $\mathrm{O}_{2}$ uptake above basal (mean $\pm \mathrm{SEM}$ ) for five preparations of unenriched cells in $A$, and in four cell preparations for $B$.

† Significantly different from $10 \mu \mathrm{M}$ carbamylcholine, $P<0.01$.

$\$$ Significantly different from basal, $P<0.05$.

"Significantly different from IMX, $P<0.05$. trin over basal and over an IMX background was similar (Table II).

The agent used to solubilize gastrin was of great importance. It was found that ammonium markedly increased oxygen uptake by mucosal cells in concentrations as low as $1 \mathrm{mM}$ (data not shown). For the present studies, gastrin was solubilized in dimethylsulfoxide. The final concentration of dimethylsulfoxide present $(0.006 \%)$ did not alter basal or stimulated oxygen uptake.

\section{The effects of atropine and metiamide on the actions of secretagogues}

Atropine. $10 \mu \mathrm{M}$ atropine caused marked inhibition of the maximal response to carbamylcholine (Fig. 6), but did not alter the response to histamine (Fig. 7), to IMX (Fig. 5), nor to gastrin (Fig. 8), nor did this concentration of atropine affect basal oxygen uptake (data not shown). $0.1 \mu \mathrm{M}$ atropine caused inhibition of the responses to submaximal doses of carbamylcholine, compatible with competitive kinetics (Fig. 6).

Metiamide. $10 \mu \mathrm{M}$ metiamide caused inhibition of the responses to submaximal doses of histamine (Fig. 7) and $0.1 \mathrm{mM}$ metiamide caused marked inhibition of the maximal response to histamine (10 $\mu \mathrm{M}$, Fig. 7). $10 \mu \mathrm{M}$ metiamide caused complete inhibition of the response to $0.1 \mathrm{mM}$ IMX (Fig. 5). Neither $0.1 \mathrm{mM}$ nor $10 \mu \mathrm{M}$ metiamide altered the response to carbamylcholine (Fig. 6, Table III), nor to gastrin (Fig. 8, Table III), nor was basal oxygen altered by $0.1 \mathrm{mM}$ metiamide (Table III). $1 \mathrm{mM}$ metiamide caused a small decrease

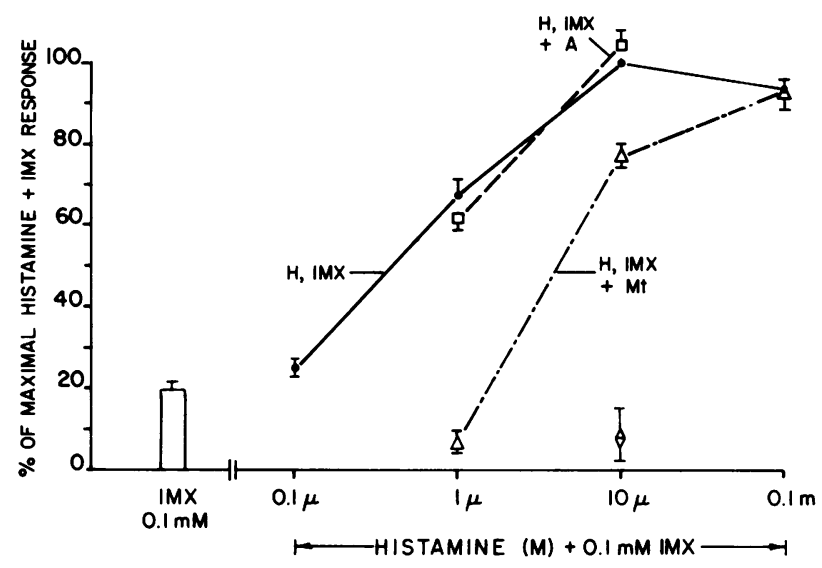

FIGURE 7 The effects of metiamide and atropine on the doseresponse relation to histamine plus IMX. Oxygen uptake was determined for unenriched mucosal cells and expressed as the percentage of the maximal increment above basal produced by histamine plus IMX. The data are the means \pm SE from five preparations for histamine plus IMX plus $10 \mu \mathrm{M}$ atropine $(\square)$, histamine plus IMX plus $10 \mu \mathrm{M}$ metiamide $(\Delta)$, and histamine plus $0.1 \mathrm{mM}$ IMX plus $0.1 \mathrm{mM}$ metiamide $(\ominus)$. 


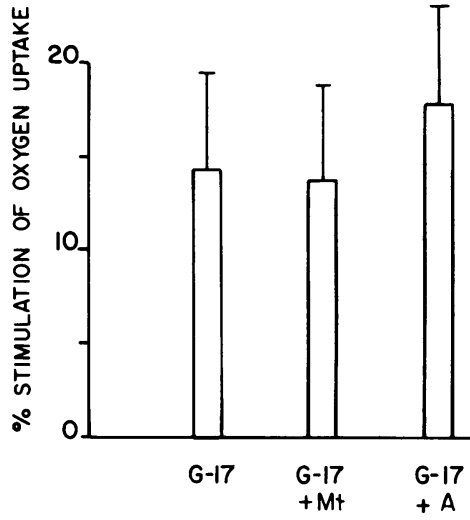

FIGURE 8 The effects of metiamide and atropine on gastrinstimulated oxygen uptake. The data are the mean of from 6 to 10 tests of oxygen uptake for each treatment group in four cell preparations, $\pm \mathrm{SE}$, based upon preparation means. Agents were used in the following concentrations: $0.1 \mu \mathrm{M}$ gastrin, $10 \mu \mathrm{M}$ metiamide, and $10 \mu \mathrm{M}$ atropine.

in both basal oxygen uptake and the response to carbamylcholine (Table III).

\section{DISCUSSION}

The method for the isolation of gastric mucosal cells described here entailed use of mucosa that had been separated free from submucosa and then sequentially incubated with crude collagenase and EDTA. The use of separated mucosa and the calcium chelation step each greatly enhanced enzyme digestion, thereby allowing use of lower concentrations of collagenase and avoiding the requirement for enzyme preparations with higher proteolytic activity. Mucosal cells isolated by these techniques were viable and the response of these cells to secretagogues indicated that their plasma membrane components were largely intact.

In the present study, oxygen consumption by unenriched and parietal cell-enriched fractions of canine

TABLE III

Effects of $1 \mathrm{mM}$ and $0.1 \mathrm{mM}$ Metiamide on Oxygen Uptake

\begin{tabular}{lcc}
\hline \multicolumn{1}{c}{ Agent } & $\mathrm{O}_{2}$ uptake $^{*}$ & Number of tests \\
\hline & $\%$ & $n$ \\
C, $1 \mathrm{mM}$ & $37.1 \pm 1.5$ & 6 \\
C, $1 \mathrm{mM}+\mathrm{Mt}, 0.1 \mathrm{mM}$ & $38.6 \pm 1.4$ & 8 \\
C, 1 mM + Mt, 1 mM & $26.3 \pm 0.6$ & 8 \\
G-17, 0.1 $\mu \mathrm{M}$ & $9.4 \pm 1.3$ & 12 \\
G-17, 0.1 $\mu \mathrm{M}+\mathrm{Mt}, 0.1 \mathrm{mM}$ & $7.8 \pm 1.1$ & 8 \\
Mt, 0.1 mM & $2.0 \pm 1.0$ & 8 \\
Mt, 1 mM & $-11.1 \pm 1.6$ & 10 \\
\hline
\end{tabular}

* Percentage increase in oxygen uptake above basal (mean $\pm \mathrm{SE}$ ) based upon the indicated number of tests pooled from two preparations. fundic mucosal cells was used as an index of the physiological response of parietal cells to secretagogues. Several observations, both from the literature and from the present study, support the validity of this approach.

(a) In systems such as the ex vivo stomach preparation $(16,17)$ and the isolated amphibian mucosa $(15)$, where all cellular elements of the mucosa are present and where both oxygen consumption and acid secretion can be directly measured simultaneously, a strong linear correlation exists between the stimulation of acid secretion and the stimulation of oxygen consumption by secretagogues. It is possible that the increases in oxygen uptake reflect processes in addition to the secretion of acid such as biosynthesis of parietal cell membrane protein. The abundant mitochondria and sparse rough endoplasmic reticulum in the parietal cell render this latter alternative less attractive.

(b) In the present studies with cell fractions obtained using the elutriator rotor, the basal oxygen uptake was closely correlated with the parietal cell content of the fractions, with the $y$ intercept of the linear regression line corresponding to the basal oxygen uptake for the parietal cell-depleted fractions. The histamine plus IMX-, carbamylcholine-, and gastrin-stimulated increment in oxygen uptake above basal was also closely correlated with the parietal cell content of the fractions. The $y$ intercept for each of these three regression lines were not significantly different from zero, consistent with the observations that oxygen uptake was not increased with stimulation in the parietal cell-depleted fractions. It appears that the stimulation of oxygen uptake observed in the enriched as well as the unenriched preparations may be interpreted as reflecting mainly parietal cell function. Mucosal cells other than parietal cells may also increase oxygen uptake with stimulation; however, the present techniques failed to detect such a response.

In light of the above points and the observations that the normalized dose-response relations were similar in the crude and enriched parietal cell fractions, the crude preparations were used for many of the present studies. A higher total cell concentration was used to compensate for the lower parietal cell content of these unenriched fractions.

(c) Parietal cells stimulated by histamine, gastrin, acetylcholine, and isobutyl methyl xanthine show an increased rate of uptake of $\left[{ }^{14} \mathrm{C}\right]$ aminopyrine (21). Aminopyrine is a weak base with a pKa of 5.0 so its partition between two compartments would be greatly enhanced if one compartment had a $\mathrm{pH}$ at or below the pKa. The cellular accumulation of aminopyrine with stimulation is evidence for the actual secretion of acid by isolated parietal cells.

(d) With stimulation isolated parietal cells undergo a specific morphological transformation characterized 
by the appearance of prominent canaliculi lined with microvilli (22), similar to that originally described by Sedar studying intact mucosa (23). This transformation is further evidence that these in vitro responses of parietal cells to secretagogues reflect cellular events similar to those that occur in vivo.

In the present studies, oxygen consumption by mucosal cells was stimulated by histamine, gastrin, carbamylcholine, and IMX. Histamine alone produced a small increase in oxygen uptake which was greatly enhanced by IMX. The sensitivity of isolated parietal cells to histamine (plus IMX) and carbamylcholine was similar to that reported by others using in vitro systems (24-29). The stimulation of oxygen uptake by gastrin, although of statistical significance, was of small magnitude suggesting that gastrin as a single agent is a weak stimulant of the parietal cell. It must be kept in mind, however, that the magnitude of the gastrin response as well as of the other responses may have been attenuated by treatment with the collagenase preparation, by the calcium chelation step, or by the conditions of incubation. This small response to gastrin was however markedly enhanced by interaction with histamine (5). These studies of oxygen consumption have been performed between 10 and 20 min after the onset of stimulation. The rates of oxygen consumption during this period of study in general remained constant. It is possible, however, that the pattern of secretagogue stimulation would differ in studies conducted over longer time periods.

Several observations suggest that gastrin, acetylcholine, and histamine each have direct and independent actions on parietal cells. The inhibitory effects of anticholinergics and $\mathrm{H}_{2}$ receptor antagonists on the actions of secretagogues were specific: histamine stimulation was inhibited by metiamide but was not inhibited by atropine; carbamylcholine stimulation was inhibited by atropine but was not inhibited by metiamide; and gastrin stimulation was inhibited by neither atropine nor metiamide. ${ }^{6}$ The specificity of inhibition by metiamide and atropine thus indicated separate and specific receptors on the parietal cell for histamine, gastrin, and acetylcholine. If the actions of gastrin or acetylcholine were necessarily mediated by histamine, then one would expect inhibition of these actions by metiamide, which was not observed.

The poor response of parietal cells isolated by these techniques to histamine alone is in contrast to the potent effects of histamine in vivo. The reason for this decay in responsiveness to histamine is unknown. The

\footnotetext{
${ }^{6}$ These specific effects of metiamide are demonstrated at concentrations below $0.1 \mathrm{mM}$. At $1 \mathrm{mM}$, metiamide did display inhibition of basal oxygen uptake as well as carbamylcholine stimulation. Effects of metiamide at these very high concentrations are likely to be nonspecific in that these effects do not result from blockade of the $\mathrm{H}_{2}$ receptor.
}

stimulation of isolated parietal cells by histamine was however markedly enhanced by IMX. IMX alone stimulated oxygen uptake and this effect was inhibited by $10 \mu \mathrm{M}$ metiamide. At this concentration metiamide appears to be specific for histamine (vide supra), thus suggesting that the effect of IMX alone may result from potentiation of residual endogenous histamine. In contrast to the marked potentiation of histamine by IMX, IMX caused much less enhancement of gastrin and carbamylcholine. IMX is a potent phosphodiesterase inhibitor, but this agent also has actions which are independent of phosphodiesterase inhibition such as stimulation of contraction of isolated papillary muscle (30). In isolated mucosal cells prepared by the present method, stimulation by histamine, but not stimulation by gastrin nor carbamylcholine, was associated with increases in cellular cyclic AMP (31). This effect of histamine on cyclic AMP was correlated with the degree of parietal cell enrichment of the fractions and also was markedly enhanced by the presence of IMX. These observations support the view that the enhancement by IMX of the histamine stimulation of oxygen uptake by isolated parietal cells depends upon inhibition of phosphodiesterase activity and therefore also support the hypothesis that histamine action on parietal cells is mediated by the generation of cyclic AMP.

The present data are consistent with a model in which the parietal cell has specific receptors for histamine, gastrin, and acetylcholine and in which anticholinergics and $\mathrm{H}_{2}$-receptor antagonists are specific in their actions against acetylcholine and histamine, respectively. Such a model appears at odds with the in vivo observations that anticholinergics and $\mathrm{H}_{2}$-antagonists display an apparent lack of specificity. One possible explanation of this apparent contradiction is provided by a consideration of the effects of these inhibitors on the interactions that occur between secretagogues, a topic dealt with in detail elsewhere (5).

\section{ACKNOWLEDGMENTS}

The author is indebted to Doctors Morton I. Grossman and John $\mathbf{H}$. Walsh for the invaluable support and direction that they have offered and to Raymond L. Melendez and Aija Fox for their dedicated and indispensible involvement in the development and application of these techniques. The author is also indebted to Doctors Jon Isenberg, Armin Wollin, Travis Solomon, and Charles Code for their many helpful discussions and contributions, to Dr. Paul Guth and Gary Paulsen for assisting with the histologic studies, to Doctors Janet Elashoff and Joseph Steinbach for guidance in statistical analyses, and to Dr. O. M. Griffith of the Spinco Applications Division of Beckman Instruments (Palo Alto, Calif.) for his collaboration on the initial cell separation studies. The author is also grateful to Doctors Fabian Michaelangeli and Terry Machen for their helpful suggestions at the inception of these studies, and to Mrs. Ruth Abercrombie for excellent secretarial assistance.

This project was supported, in part, by the Center for Ulcer 
Research and Education (National Institute of Arthritis, Metabolism, and Digestive Diseases grant AM 17328) and grant AM 19984, also from the National Institute of Arthritis, Metabolism, and Digestive Diseases.

\section{REFERENCES}

1. Soll, A. H. 1975. Isolated canine gastric mucosal cells: stimulation of oxygen uptake by pentagastrin and acetylcholine. Physiologist. 18: 398. (Abstr.)

2. Soll, A. H. 1976. The isolated mammalian parietal cell: actions and interactions of secretagogues. Gastroenterology. 70: 794. (Abstr.)

3. Grossman, M. I. 1967. Neural and hormonal stimulation of gastric secretion of acid. Handb. Physiol. 2(Sect. 6): 835863.

4. Code, C. F. 1965. Histamine and gastric secretion; a later look, 1955-1965. Fed. Proc. 24: 1311-1321.

5. Soll, A. H. 1978. The interaction of histamine with gastrin and carbamylcholine on oxygen uptake by isolated mammalian parietal cells. J. Clin. Invest. 61: 381-389.

6. Walder, A. I., and J. B. Lunseth. 1963. A technique for separation of the cells of the gastric mucosa. Proc. Soc. Exp. Biol. Med. 112: 494-496.

7. Croft, D. N., and F. J. Ingelfinger. 1969. Isolated gastric parietal cells: oxygen consumption, electrolyte content and intracellular pH. Clin. Sci. (Oxf.). 37: 491-501.

8. McDougal, W. S., and J. J. DeCosse. 1970. Method for determining differential secretory function of isolated cells in vitro: chloride movement in isolated parietal cells. Exp. Cell Res. 61: 203-206.

9. Blum, A. C., G. T. Shah, V. D. Wiebelhaus, F. T. Brennan, H. F. Helander, R. Ceballos, and G. Sachs. 1971. Pronase method for isolation of viable cells from necturus gastric mucosa. Gastroenterology. 61: 189-200.

10. Glick, D. M, 1974. Simulated chloride transport by isolated parietal cells. Biochem. Pharmacol. 23: 3283-3288.

11. Lewin, M., A. M. Cheret, A. Soumarmon, and J. Girodet. 1974. Methode pour l'isolement et le tri des cellules de la muqueuse fundique de rat. Biol. Gastroent. 7: 139-144.

12. Michelangeli, F. 1974. Secretory properties of isolated oxyntic cells from gastric mucosa. Proc. Int. Union Physiol. Sci. 11: 397. (Abstr.)

13. Romrell, L. J., M. R. Coppe, D. R. Munro, and S. Ito. 1975. Isolation and separation of highly enriched fractions of viable mouse gastric parietal cells by velocity sedimentation. J. Cell Biol. 65: 428-438.

14. Amsterdam, A., and J. D. Jamieson. 1974. Studies on dispersed pancreatic exocrine cells. I. Dissociation technique and morphologic characteristics of separated cells. J. Cell Biol. 63: 1037-1056.

15. Hersey, S. J. 1974. Interactions between oxidative metabolism and acid secretion in gastric mucosa. Biochim. Biophys. Acta. 344: 125-203.

16. McQuarrie, D. G., A. Eichenholz, A. S. Blumenthals, and
J. A. Vennes. 1967. Kinetics of gastric juice secretion: a correlation of arteriovenous differences with the composition of the gastric juice. Surgery. 62: 475-486.

17. Kowalewski, K., and A. Kolodej. 1972. Relation between hydrogen ion secretion and oxygen consumption by ex vivo isolated canine stomach, perfused with homologous blood. Can. J. Physiol. Pharmacol. 50: 955-961.

18. McEwen, C. R., R. W. Stallard, and E. T. Juhos. 1968. Separation of biological particles by centrifugal elutriation. Anal. Biochem. 23: 369-377.

19. Altman, P. L., and D. S. Dittmer, editors. 1971. Respiration and circulation. Committee on Biological Handbooks, Federation of American Society for Experimental Biology, Bethesda, Maryland. 18.

20. Dixon, W. J., and F. J. Massey. 1969. Introduction to Statistical Analysis. McGraw-Hill Book Co., Inc., New York. 3rd edition. 638 pp.

21. Soll, A. H. 1977. Secretagogue stimulation of $\mathrm{O}_{2}$ consumption and ${ }^{14} \mathrm{C}$-aminopyrine uptake by enriched parietal cells. Gastroenterology. 72: 1166. (Abstr.)

22. Soll, A. H., J. Lechago, and J. H. Walsh. 1976. The isolated mammalian parietal cell: morphological transformation induced by secretagogues. Gastroenterology. 70: 975. (Abstr.)

23. Sedar, A. W. 1961. Fine structure of the stimulated oxyntic cell. Fed. Proc. 24: 1360-1367.

24. Shoemaker, R. L., B. I. Hirschowitz, and G. Sachs. 1967. Hormonal stimulation of necturus gastric mucosa in vitro. Am. J. Physiol. 212: 1013-1016.

25. Alonso, D., and J. B. Harris. 1965. Effect of xanthines and histamine on ion transport and respiration by frog gastric mucosa. Am. J. Physiol. 208: 18-23.

26. Kasbekar, D. K. 1967. Studies of resting isolated frog gastric mucosa. Proc. Soc. Exp. Biol. Med. 125: 267-271.

27. Nakajima, S. 1972. Some physiological characteristics of in vitro gastric mucosa: responses to pharmacological agents and gastrointestinal hormones. In Gastric Secretion. G. Sachs, E. Heinz, and K. J. Ullrich, editors. Academic Press, Inc., New York. 225-236.

28. Forte, J. G., and L. A. Solberg, Jr. 1973. Pharmacology of isolated amphibian gastric mucosa. In Pharmacology of Gastrointestinal Motility and Secretion. P. Holton, editor. Permagon Press, Elmsford N. Y. 195-260.

29. Berglindh, T., H. F. Helander, and K. J. Obrink. 1976. Effects of secretagogues on oxygen consumption, aminopyrine accumulation and morphology in isolated gastric glands. Acta. Physiol. Scand. 97: 401-414.

30. Chapman, R. A., and D. J. Miller. 1974. Structure-activity relations for caffeine: a comparative study of the inotropic effects of the methylxanthines, imidazoles and related compounds on the frog's heart. J. Physiol. 242: 615-634.

31. Soll, A. H., and A. W. Wollin. 1977. The effects of histamine, prostaglandin $E_{2}$, and secretin on cyclic AMP in separated canine fundic mucosal cells. Gastroenterology. 72: 1166. (Abstr.) 